\title{
Determination of genome size of four Propionibacterium species by pulsed-field gel electrophoresis
}

\author{
M Gautier 1, N Mouchel 2, A Rouault 1, P Sanséau 2 \\ 1 INRA, Laboratoire de Recherches de Technologie Laitière, 65 rue de St Brieuc; \\ 2 Université de Rennes I, Laboratoire de Biologie Moléculaire, \\ 263 av général Leclerc, 35000 Rennes, France
}

(Received 29 April 1992; accepted 11 May 1992)

\begin{abstract}
Summary - The 2 restriction enzymes $X b a l$ and Sspl were found to produce DNA fragment distributions convenient for genome analysis of dairy propionibacteria species $(P$ acidipropionici, $P$ freudenreichii, $P$ jensenii and $P$ thoenii) by pulsed-field gel electrophoresis. These restriction enzymes produced 10-19 fragments with sizes ranging from 5-1000 kilobases $(\mathrm{kb})$ depending on the strains. The entire genome size was estimated to be approximately $2300-3200 \mathrm{~kb}$ depending on the species.
\end{abstract}

Propionibacterium spp / genome size / pulsed-field gel electrophoresis

Résumé - Détermination, par électrophorèse en champs pulsés, de la taille du génome de 4 espèces de Propionibacterium. Parmi plusieurs endonucléases de restriction testées, deux enzymes (Xbal et Sspl) ont été utilisées de manière à générer une distribution de fragments bien adaptée à une analyse en champs pulsés du génome des bactéries propioniques laitières $(\mathrm{P}$ acidipropioni$\mathrm{ci}, \mathrm{P}$ freudenreichii, $\mathrm{P}$ jensenii et $\mathrm{P}$ thoenii). Ces enzymes de restriction produisent suivant les souches 10 à 19 bandes dont les tailles varient de 5 à 1000 kilobases $(\mathrm{kb})$. La taille du génome varie suivant les espèces et s'échelonne de 2300 à $3200 \mathrm{~kb}$.

Propionibacterium spp / taille du chromosome / électrophorèse en champs pulsés

\section{INTRODUCTION}

Dairy propionibacteria are involved in Swiss cheese-making as essential ripening starters (Langsrud and Reinbold, $1973 a, b)$ and in several industrial fermentations (production of propionic acid and vitamin $B_{12}$ ). Existing knowledge on the Propionibacterium genome is quite limited (Hofherr and Glatz, 1983; Perez Chaia et al, 1988; Rehberger and Glatz, 1990) and needs to be extended in order to improve existing industrial strains used in dairy starters.

The genomes of dairy propionibacteria have a $\mathrm{G}+\mathrm{C}$ content that ranges from 64 $68 \%$ (Johnson and Cummins, 1972) but its size is still unknown. This high $\mathrm{G}+\mathrm{C}$ content means that restriction enzymes with recognition sequences rich in $\mathrm{A}$ and 
T nucleotides should digest the Propionibacterium chromosome only in a few sites, yielding large fragments that may be separated by pulsed-field gel electrophoresis techniques (PFGE) (Cantor et al, 1988; Lai et al, 1989). This technique has been used to separate whole chromosomes up to $9000 \mathrm{~kb}$ in size (Chu et al, 1986; Cantor et al, 1988; Smith et al, 1988). The analysis of restriction fragments has been applied to estimate the size of bacterial chromosomes (Chen et al, 1986; Su and Baseman, 1990).

In this paper we describe the use of PFGE to determine the genome size of Propionibacterium using chromosomal digestion by restriction endonucleases $X b a l$ (T/CTAGA) and Sspl (AAT/ATT), which as expected, produce large fragments compared to other endonucleases.

\section{MATERIALS AND METHODS}

\section{Bacterial strains}

The Propionibacterium strains (table I) were obtained from the ATCC (American Type Culture Collection), CIP (Institute Pasteur Collection), CNRZ (Centre National de Recherches Zootechniques, France), DSM (Deutsche Sammlung von Mikroorganismen und Zellkulturen $\mathrm{GmbH}$ ) and the TL (INRA Dairy Technology Laboratory Collection, Rennes, France). The lytic enzymes lysozyme or mutanolysin were not efficient enough to digest the cell wall of most strains of dairy Propionibacterium; the cells were therefore made fragile by growth for 2 days on YEL medium (Hettingha et al, 1968), which contained $0.5 \mathrm{~mol} / \mathrm{l}$ sucrose supplemented with various concentrations of glycine (w/v) depending on the strains: $0.5 \%$ for CIP 6434 and CNRZ 729, $1 \%$ for TL 2500 and CNRZ 732, $1.5 \%$ for CIP 6435 and CNRZ $85,2 \%$ for CNRZ 79, ATCC 4875 and CIP $103026,3 \%$ for CNRZ 87. All the cultures were harvested at an optical density (OD) of 0.3 at $650 \mathrm{~nm}$. The Escherichia coli K12 strain was grown at $37^{\circ} \mathrm{C}$ on LuriaBertani medium (Maniatis et al, 1982) to an OD of 0.4 . In order to synchronize replication forks, chloramphenicol $(180 \mu \mathrm{g} / \mathrm{ml})$ was added (Ohki and Smith, 1989), and shaking was continued for $1 \mathrm{~h}$.

\section{Genomic DNA preparation}

DNA was embedded in low melting point agarose to prepare DNA insert as described by McClelland et al (1987). Ten $\mathrm{ml}$ of culture, grown as described previously, were harvested and suspended in $10 \mathrm{ml}$ of TES buffer (Tris- $\mathrm{HCl}$ $0.05 \mathrm{~mol} / \mathrm{l}, \mathrm{Na}_{2}$ EDTA $0.010 \mathrm{~mol} / \mathrm{h}, \mathrm{pH} 8.0,0.5$ $\mathrm{mol} / \mathrm{l}$ sucrose). After centrifugation $(5000 \mathrm{~g}, 10$ $\mathrm{min}$ ) the cells were suspended in $0.5 \mathrm{ml}$ of TE buffer (Tris- $\mathrm{HCl} 0.05 \mathrm{~mol} / \mathrm{l}, \mathrm{Na}_{2}$ EDTA $0.01 \mathrm{~mol} /$ I, $\mathrm{pH} 8.0$ ). Low melting point agarose (1\%) (NuSieve) in TE buffer was added to each cell suspension. A $100-\mu l$ volume of the cell-agarose mixture was poured into $150-\mu \mathrm{l}$ molds. Each agarose block was washed in TE and incubated at $37^{\circ} \mathrm{C}$ for $4 \mathrm{~h}$ in a buffer: TE with lysozyme (Afilact France, $20 \mathrm{mg} / \mathrm{ml}$ ), and $0.05 \%$ lauroyl sarcosine. The blocks were washed with TE and suspended in a lysis solution $(0.1 \mathrm{mo} / /$ EDTA, Tris $0.01 \mathrm{~mol} / \mathrm{l} \mathrm{pH} 8.01 \%$ SDS, $1 \mathrm{mg} / \mathrm{ml}$ proteinase $K$ (Boehringer Mannheim). This was followed by incubation at $50{ }^{\circ} \mathrm{C}$ for $24 \mathrm{~h}$. The blocks were washed with TE, suspended in a phenylmethylsulfonylfluoride (PMSF) solution $(175 \mu \mathrm{g} / \mathrm{ml}$ in $T E$ ), and incubated at room temperature for $1 \mathrm{~h}$. The blocks were finally washed 3 times with TE buffer and stored in the buffer at $4^{\circ} \mathrm{C}$.

\section{Genomic DNA digestion and pulsed-field gel electrophoresis}

Restriction enzymes were obtained from Boehringer. The agarose blocks were washed extensively with TE. Each plug was incubated at room temperature for $12 \mathrm{~h}$ in $500 \mu \mathrm{l}$ of restriction enzyme buffer. For digestion, each plug was incubated overnight in $200 \mu \mathrm{l}$ of restriction enzyme buffer with $50 \mathrm{U}$ of restriction enzyme. The restricted block could be stored at $4{ }^{\circ} \mathrm{C}$ in $0.5 \mathrm{~mol} / \mathrm{l}$ EDTA for a few days.

The pulsed field gel electrophoresis was performed on a Bio-Rad CHEF DRII electrophoresis cell (Lai et al, 1989). The samples were migrated through $1 \%(w / v)$ agarose gels in a 
Table I. Size (kb) of restriction fragments obtained after digestion with Xbal or Sspl of the chromosome of various Propionibacterium strains. Taille des bandes $(\mathrm{kb})$ obtenues après digestion du chromosome de différentes souches de Propionibacterium avec Xbal et Sspl.

\begin{tabular}{|c|c|c|c|c|c|c|c|c|c|c|c|c|c|c|}
\hline \multicolumn{3}{|c|}{ P acidipropionici } & \multicolumn{4}{|c|}{$P$ freudenreichii } & \multicolumn{4}{|c|}{$P$ jensenii } & \multicolumn{4}{|c|}{$P$ thoenii } \\
\hline \multicolumn{2}{|c|}{ ATCC 4875} & \multirow{2}{*}{$\frac{\text { DSM20273 }}{\mathrm{Xbal}}$} & \multicolumn{2}{|c|}{ CIP 103208} & \multirow{2}{*}{$\frac{T L 2500}{\mathrm{Xbal}}$} & \multirow{2}{*}{$\frac{C N R Z 729}{\text { Xbal }}$} & \multicolumn{2}{|c|}{ CIP 6435} & \multicolumn{2}{|c|}{ CNRZ 87 CNRZ 79} & \multicolumn{2}{|c|}{ CIP 6434} & \multicolumn{2}{|c|}{ CNRZ 732 CNRZ 85} \\
\hline Ssp I & Xbal & & Ssp/ & Xbal & & & Ssp/ & Xbal & Xbal & Xbal & Ssp/ & Xbal & Xbal & Xbal \\
\hline 360 & 270 & 300 & 450 & 650 & 360 & 360 & 1000 & 270 & 270 & 260 & 360 & 270 & 250 & 360 \\
\hline 250 & 240 & 240 & 245 & 245 & 250 & 270 & 270 & 245 & 260 & 215 & 240 & 230 & 240 & 250 \\
\hline 230 & 240 & 235 & 245 & 245 & 250 & 245 & 245 & 240 & 248 & 215 & 225 & 215 & 210 & 245 \\
\hline 230 & 220 & 230 & 210 & 210 & 230 & 245 & 208 & 210 & 245 & 205 & 210 & 215 & 205 & 245 \\
\hline 218 & 220 & 220 & 203 & 203 & 225 & 210 & 130 & 200 & 245 & 205 & 210 & 205 & 203 & 205 \\
\hline 210 & 210 & 205 & 195 & 200 & 200 & 208 & 80 & 200 & 210 & 195 & 200 & 205 & 195 & 205 \\
\hline 205 & 205 & 205 & 130 & 190 & 200 & 204 & 40 & 180 & 205 & 195 & 175 & 200 & 195 & 190 \\
\hline 205 & 205 & 180 & 110 & 110 & 191 & 180 & 25 & 180 & 190 & 103 & 150 & 105 & 190 & 105 \\
\hline 200 & 200 & 120 & 110 & 100 & 100 & 106 & 10 & 105 & 110 & 102 & 120 & 105 & 160 & 105 \\
\hline 165 & 190 & 110 & 80 & 50 & 60 & 50 & & 60 & 100 & 95 & 90 & 70 & 103 & 95 \\
\hline 130 & 150 & 105 & 40 & 20 & 60 & 25 & & 60 & 45 & 90 & 70 & 70 & 45 & 45 \\
\hline 125 & 125 & 100 & 20 & 10 & & 10 & & 35 & 40 & 45 & 60 & 45 & 45 & 40 \\
\hline 110 & 125 & 98 & 15 & & & & & 35 & 30 & 40 & & 40 & & 20 \\
\hline \multirow[t]{3}{*}{100} & & 95 & 20 & & & & & 25 & 20 & 20 & & 20 & & 20 \\
\hline & & 70 & 10 & & & & & 10 & & 20 & & 20 & & 20 \\
\hline & & 70 & & & & & & 5 & & & & 20 & & \\
\hline 3173 & 3035 & 2433 & 2433 & 2603 & 2476 & 2483 & 2288 & 2420 & 2583 & 2350 & 2460 & 2365 & 2389 & 2510 \\
\hline
\end{tabular}


solution of TBE gel buffer $(0.089 \mathrm{~mol} / \mathrm{Tris}-$ borate, $0.089 \mathrm{~mol} / \mathrm{l}$ boric acid, $0.002 \mathrm{~mol} / \mathrm{l}$ EDTA, pH 8.3) $0.5 x$. The electrophoretic conditions have been indicated above the figures.

\section{RESULTS AND DISCUSSION}

A first selection of restriction endonucleases was made using the results obtained from bacteria showing a high $\mathrm{G}+\mathrm{C}$ DNA. We chose the enzymes Notl and Sfi, which recognize 8 base-pair high $\mathrm{G}+\mathrm{C}$ sequences and which have been successfully used to determine the size of the $E$ coli K12 chromosome (Smith et al, 1987).
Some enzymes with recognition sequences rich in A+T (Dral, Hpal, Ndel, Sspl, $X b a l$ and $A s n l)$ used to determine the size of the Pseudomonas aeruginosa genome which has a high $\mathrm{G}+\mathrm{C}$ content were also employed (Hector and Johnson, 1990). Moreover, the restriction site of Xbal and Sspl containing the stop codon TAG appears very infrequently on the $E$ coli chromosome (Condemine and Smith, 1990). All these restriction enzymes have been tested on 4 representative strains of Propionibacterium ( $P$ acidipropionici ATCC 4875, $P$ freudenreichii CIP 103026, $P$ jensenii CIP 6435 and $P$ thoenii CIP 6434). The results obtained with strain ATCC
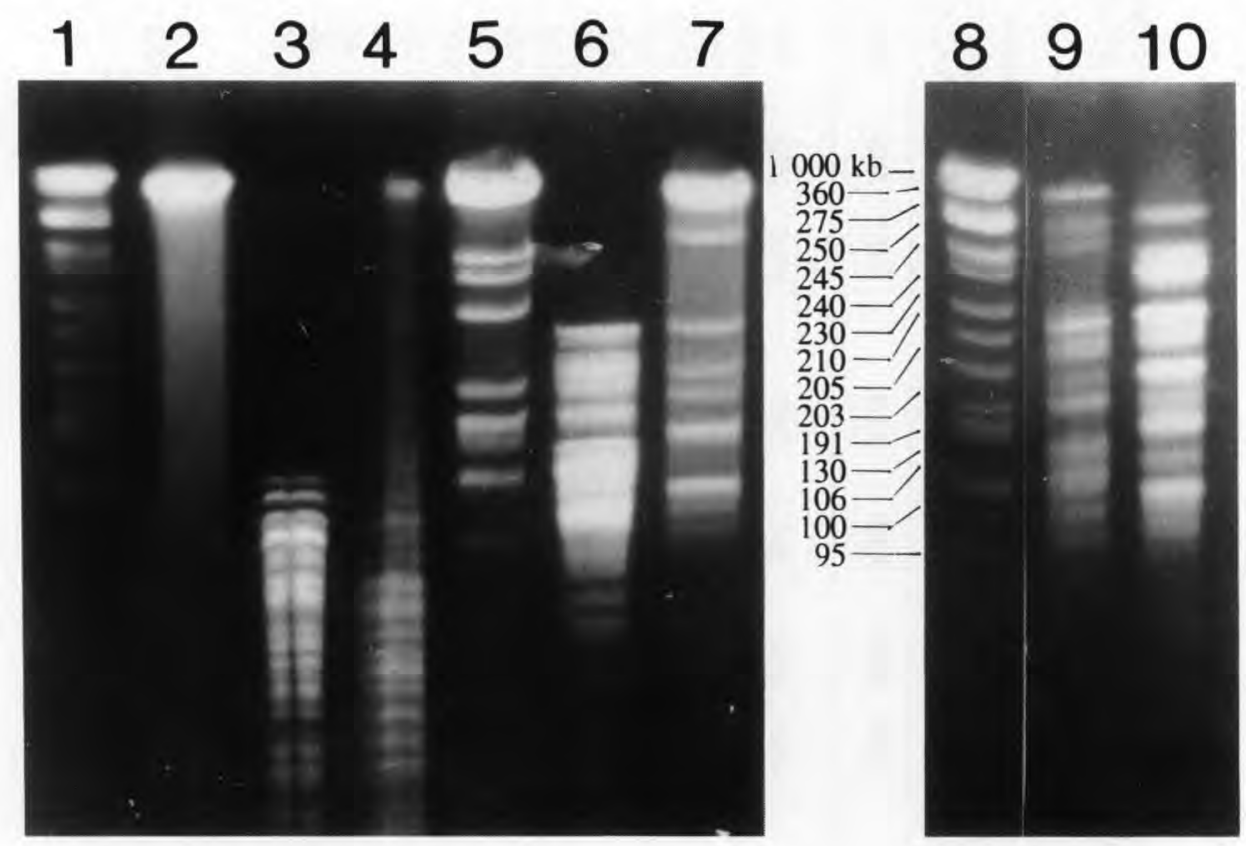

Fig 1. PFGE of DNA from $P$ acidipropionici strain ATCC4875 digested with various restriction enzymes. Lane 2: Dral. Lane 3: Notl. Lane 4: Sfil. Lane 5: Asnl. Lane 6: Ndel. Lane 7: Hpal. Lane 9: Sspl. Lane 10: Xbal. Lane 1 and Lane 8, E coli $\mathrm{K} 12$ chromosome digested with Notl. Running conditions were $200 \mathrm{~V}$ for $16 \mathrm{~h}$ with a $20 \mathrm{~s}$ pulse time at $14^{\circ} \mathrm{C}$.

PFGE de l'ADN de la souche de $\mathrm{P}$ acidipropionici ATCC4875 digéré avec différentes endonucléases de restriction. Piste 2 : Dral. Piste 3 : Notl. Piste 4 : Sfil. Piste 5: Asnl. Piste $6:$ Ndel. Piste $7:$ Hpal. Piste 9 : Sspl. Piste 10 : Xbal. Pistes 1 et 8 : chromosome de E coli K12 digéré avec Notl. Les paramètres de migration étaient de $200 \mathrm{~V}$ à $14^{\circ} \mathrm{C}, 16 \mathrm{~h}$ avec une fréquence d'impulsion de $20 \mathrm{~s}$. 
4875 are presented in figure 1 ; they were similar for the 3 other strains (data not shown). Some enzymes used to determine the size of the Pseudomonas genome (Dral and Asnl) presented none or only a few cut sites in the Propionibacteria genomes. Other enzymes, such as Spel, had more complex patterns which were difficult to analyse. The restriction endonucleases Notl and Sfi produced too many restriction fragments. Digestion of the chromosomal DNA with $X b a l$ and Sspl (fig 1, lanes 9 and 10) seemed to be most suitable for genome size determination, since the resulting pattern was more simple to analyse, the fragments produced were large and the genome was cut into fewer than 20 bands.

Figure 2 shows the restriction profiles obtained with Xbal digestion of the chromosome of a representative strain of each species. The patterns obtained with Sspl (data not shown) were similar and constituted $10-16$ bands, ranging in size from $\mathrm{kb}$ approximately 10-1000. Lambda concatemers were used as markers and $E$ coli K12 was digested with Notl (Smith et al, 1987 ) in order to compare the restriction profiles. Band size has been indicated in table I.

The chromosome molecular size of each Propionibacterium species was determined by averaging the size obtained by $X$ bal or Sspl digestion of 2 (for $P$ acidipropionici) or 3 strains of each species. For $P$ acidipropionici $X b a l$ and Sspl consistently gave a genome size of approximately $3060 \mathrm{~kb}$. For $P$ freudenreichii, these enzymes gave a size of about $2500 \mathrm{~kb}$. The genorne size of $P$ jensenii was estimated to be $2410 \mathrm{~kb}$ and that of $P$ thoenii to be $2440 \mathrm{~kb}$. Moreover, the restriction patterns of these different species of Propionibacterium did not resemble one another. In comparison, the genome size of $E$ coli obtained by PFGE analysis was $4550 \mathrm{~kb}$ and that of $L$ lactis ranged from $2300-2600 \mathrm{~kb}$ (Le Bourgeois et al, 1989).

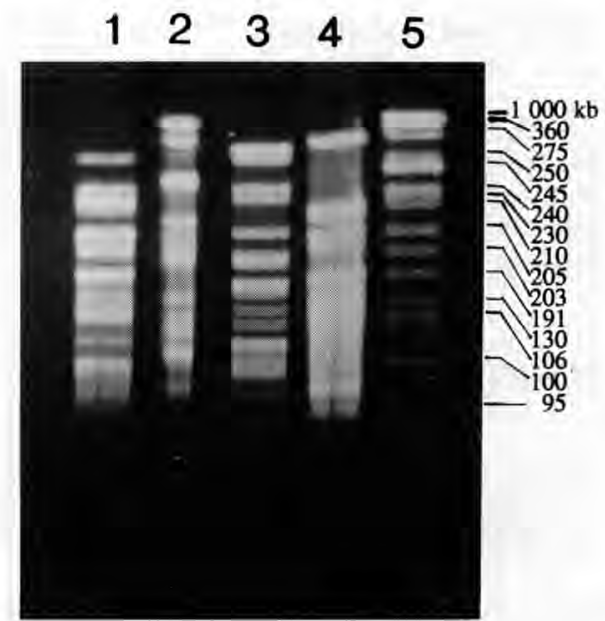

Fig 2. PFGE separation of Propionibacterium chromosome digested with $X$ bal. Lane 1: $P$ acidipropionici ATCC4875. Lane 2: $P$ freudenreichii CIP103026. Lane 3: $P$ jensenii CIP6435. Lane 4: $P$ thoenii CIP6434. Lane 5: $E$ coli chromosome digested with Notl. Running conditions were 200 $V$ for $16 \mathrm{~h}$ with a $20 \mathrm{~s}$ pulse time at $14^{\circ} \mathrm{C}$.

PFGE du génome de différentes espèces de Propionibacterium digéré ave $\mathrm{Xbal}$. Piste $1: \mathrm{P}$ acidipropionici ATCC4875. Piste $2: P$ freudenreichii CIP103026. Piste $3: \mathrm{P}$ jensenii CIP6435. Piste 4: P thoenii CIP6434. Piste 5 : chromosome de E coli K12 digéré avec Notl. Les conditions de migration étaient $200 \mathrm{~V}$ à $14{ }^{\circ} \mathrm{C}$ pendant $16 \mathrm{~h}$ avec une fréquence d'impulsion de $20 \mathrm{~s}$.

The PFGE method provides a good means of determining the genome size of Propionibacterium, a study which has not been yet published. Unlike the chemical method (Herdman, 1985) PFGE provides a direct measurement of the physical length of the DNA. Using PFGE, the fragments produced by $X$ bal and Sspl were separated and genome size determination was facilitated. This technique will be used to compare strains in our collection as has recently been proposed for lactococci (Tankskanen et al, 1990) in order to develop a simple method of identification. 


\section{ACKNOWLEDGMENTS}

This study was supported by the Region Bretagne. We thank S Lortal and P Langella for critical reading of the manuscript and JP Le Pennec for kindly providing free access to his laboratory.

\section{REFERENCES}

Cantor CR, Smith CL, Mathew MK (1988) Pulsed-field gel electrophoresis of very large DNA molecules. Annu Rev Biophys Chem $17,287-304$

Chen H, Kescler IM, Shimkets LJ (1990) Genome size of Myxococcus xanthus determined by pulsed-field gel electrophoresis. J Bacteriol 172, 4206-4212

Chu G, Vollrath D, Davis RW (1986) Separation of large DNA molecules by contour-clamped homogeneous electric fields. Science 234, 1582-1585

Condemine G, Smith CL (1990) Genetic mapping using large-DNA technology: alignment of Sfil and Arvll sites with the Notl genomic restriction map of Escherichia coli K12. In: The Bacterial Chromosome (Riley M, Drlica $K$, eds) Am Soc Microbiol, Washington DC, 53-60

Hector JSR, Johnson AR (1990) Determination of genome size of Pseudomonas aeruginosa by PFGE: analysis of restriction fragments. Nucleic Acids Res 18, 3171-3174

Herdman M (1985) The evolution of bacterial genomes: In: The Evolution of Genome Size (Cavalier-Smith T, ed) John Wiley and Sons Inc, New York, 37-68

Hettingha DH, Vedamuthu ER, Reinbold GW (1968) Pouch method for isolating and enumerating propionibacteria. J Dairy Sci 51, 1707-1709

Hofherr LA, Glatz BA (1983) Mutagenesis of strains of Propionibacterium to produce cold sensitive mutants. J Dairy Sci 66, 2482-2487

Johnson JL, Cummins CS (1972) Cell wall composition and deoxyribonucleic acid similarities among the anaerobic coryneforms, classical propionibacteria, and strains of Arachnia propionica. J Bacteriol 109, 1047-1066
Lai E, Birren BW, Clarck SM, Simon MI, Hood L (1989) Pulsed field gel electrophoresis. Biotechniques 7, 34-42

Langsrud T, Reinbold GW (1973a) Flavor development and microbiology of Swiss cheese-a review. II. Starters, manufacturing process and procedures. I Milk Food Technol 36, 531-542

Langsrud T, Reinbold GW (1973b) Flavor development and microbiology of Swiss cheese-a review. III. Ripening and flavor production. J Milk Food Technol 36, 593-609

Le Bourgeois P, Mata M, Rizenthaler P (1989) Genome comparison of Lactococcus strains by pulsed-field gel electrophoresis. FEMS Microbiol Lett 59, 65-69

Maniatis T, Fritsch EF, Sambrook J (1982) Molecular Cloning: A Laboratory Manual. Cold Spring Harbor Laboratory, New York

McClelland $M$, Jones $R$, Pates $Y$, Nelson $M$ (1987) Restriction endonucleases for pulsedfield mapping of bacterial genomes. Nucleic Acids Res 15, 5985-6005

Ohki M, Smith CL (1989) Tracking bacterial replication forks in vivo by pulsed field gel electrophoresis. Nucleic Acids Res 17, 34793490

Perez Chaia A, Sesma F, Pesce de Ruiz Holgado A, Oliver G (1988) Screening of plasmids in strains of Propionibacterium and mesophilic lactobacilli isolated from Swiss type cheeses. Microbiol Aliments Nutr 6, 171-174

Rehberger T, Glatz BA (1990) Characterization of Propionibacterium plasmids. Appl Environ Microbiol 57, 701-706

Smith CL, Econome JG, Schutt A, KIco S, Cantor CR (1987) A physical map of the Escherichia coli K12 genome. Science $236,1448-$ 1453

Smith CL, Klco S, Cantor CR (1988) Genome Analysis: A Practical Approach. IRL Press, Oxford, UK

Su CU, Baseman JB (1990) Genome size of Mycoplasma genitalium. J Bacteriol 172, 47054707

Tankskanen El, Tulloch DL, Hillier AJ, Davidson BE (1990) Pulsed-field gel electrophoresis of Smal digests of lactococcal genomic DNA, a novel method of strain identification. Appl Environ Microbiol 56, 3105-3111 